\title{
Regulating Food Insecurity and Climate Change to Attain Sustainable Development
}

\author{
Kola O. Odeku \\ Faculty of Management and Law, School of Law, University of Limpopo, South Africa
}

\section{Doi:10.5901/mjss.2014.v5n20p3064}

\begin{abstract}
The impacts of global climate change are affecting virtually all aspects of human lives and creating food insecurity. Food insecurity is one of the huge threats brought about by climate change. This is affecting the livelihood of the people and producing poverty in different dimensions especially in the developing countries. Undoubtedly, human activities are the major causes of global warming and climate change and as such, there is a need to curb them. It is against this backdrop that this paper argues for strict regulation to contain and curtail climate change by ensuring that humans act responsibly. By so doing, realization of sustainable growth and development in all aspects of human endeavours which includes food security will be realized.
\end{abstract}

Keywords: Regulatory Intervention, global climate change, food insecurity, poor, livelihood.

\section{Introduction}

Food insecurity, sustainable development and climate change are considered as the three major global challenges humanity is facing (Mertz et al 2009). Agriculture is an income source for most extremely poor and hungry people in the developing countries which include South Africa (Ahmed and Diffenbaugh, 2009). (UNFCCC, 2007). This source of income is being threatening due to the impact of climate change. There is need for drastic intervention to protect the environment in order not to compromise sustainable agriculture and economic development (Ziervogel and Ericksen, 2010).

South Africa's definition of sustainable development is influenced by the globally accepted definition provided by the Brundtland Commission. Stating the importance of the concept, Sneddon et al. (2006) say that "the concept and practice of sustainable development (SD)-as guiding institutional principle, as concrete policy goal, and as focus of political struggle-remains salient in confronting the multiple challenges of this new global order" (Sneddon et al. 2006). This definition is entrenched in Section 24 (b) (ii) of the Constitution of the Republic of South Africa. It guarantees everyone the right to having "the environment protected, for the benefit of present and future generations, through reasonable legislative and other measures that secure ecologically sustainable development and use of natural resources while promoting justifiable economic and social development." South Africa has formalized its definition of sustainable development by passing it into law (Marcuse, 1998). The definition of sustainable development in the National Environmental Management Act (NEMA), (Act No. 107 of 1998) is as follows:

"Sustainable development means the integration of social, economic and environmental factors into planning, implementation and decision-making so as to ensure that development serves present and future generations."

Sustainable development reflects a process that meets the needs of the present, without compromising the ability of future generations to meet their own needs (Redclift, 1993). Sustainable development seeks to combat the idea that, in moving away from traditional sources of energy, civilisation would thereby be forced to sacrifice growth, innovation and progress. Sustainable development is also referred to as Intergenerational Equality (Ekins, 2002). This is based on the perception that that we should share natural resources with people who are alive, but also with future generations that will continue live on the planet earth. (Stewart and Horsten, 2009). It is therefore important to point out that while a certain amount of the planet's resources can be used, the entire nature resource should never be depleted (Barnett and Morse, 2013). Sustainability is about enhancing human well-being and quality of life for all time, particularly those most affected by poverty and inequality (Dietz et al. 2009). Natural resources should be used efficiency and responsibly, this are the core principles of sustainable development (Labuschagne et al. 2005). If this generation leaves the next generation with degraded economic, social and environmental assets and less wealth, then the result will be an unsustainable future 
(Wackernagel and Rees, 1998).

Climate change is a significant and lasting variation in the statistical distribution of weather patterns over periods ranging from decades to millions of years (Denton et al. 2002). It aggravates and multiplies threat and in the process cause tension and insurmountable calamities (Zehetner, 2013). It increases a range of livelihood threats and vulnerabilities, rather than being an isolated specific risk (NFSD 2008). Over the centuries, human societies have developed the capacity to adapt to environmental change and climate variability (NFSD 2008). These adaptations include practicing shifting cultivation, adopting new crop varieties and modifying grazing patterns (NFSD 2008). But today, the speed and intensity of climate change are outpacing the speed of those autonomous actions and it is threatening the ability of poor smallholders and rural societies to cope (Mertz et al 2009).

Majority of the poorest people continue to live in rural areas and depend on agriculture for their livelihoods ( Rigg, 2006). However, they are mostly ignorant of legal measures and policies to prevent environmental degradation, erosion of natural resources and biodiversity loss (Martínez-Alier, 1993). As a result of these, they have challenges of compelling implementation and enforcement of the policies and laws to reduce the impact of climate change (Mainka et al. 2005). Persistent manifestation of weather calamities with lack of their ability to cope and adapt to climate change are seriously impacting on food security (Gregory and Ingram, 2005). It is a known fact that the industrialized countries of the developed world played a major role in emitting massive amounts of greenhouse gases causing global change (Bodansky, 2001). However, developing Africa countries are feeling the most impact of climate change and yet incapable to hold the developed world responsible (Peart and Wilson, 1998). The numerous international instruments and agreements have indicated that climate change is a global problem requiring a global solution, and that it has become the common concern and responsibility of humanities (Lafferty, 1996). It is against the backdrop of this that in order to minimize the adverse impact of climate change, it is important that the member state to the convention implement vast domestic regimes to rapidly reduce their national greenhouse gas emissions in order to achieve global reduction (Smith et al. 2007).

As part of its responsibility to tackle challenges of climate change, South Africa has involved virtually all the sectors in the economy and the government institutions giving guidelines on how to curb the surge (Yamin and Depledge, 2004). The judiciary is not an exemption and it has provided useful jurisprudence on climate change. A reference is made to the following recent case law where section 24 of the Constitution of the Republic of South Africa was subject to interpretation. In the case of Fuel Retailers Association of Southern Africa v Director General Environmental Management, Department of Agriculture, Conservation and Environment, Mpumalanga Province 2007 (6) SA 4 (CC) where the court stressed the importance of protecting the environment for present and future generatioins. In order to tackle climate change challenges, there is need to strengthen implementation and enforcement of the policies and laws.

\section{Background}

In South Africa, before the democratic dispensation, there were laws in place regulating environment (Fuggle et al. 2009). More importantly, the 1996 Republican Constitution explicitly provides for environmental rights in section 24.

Section 24 of the constitution in paragraph (a) guarantees a healthy environment to everyone in general, while paragraph (b) mandates the State to take certain measures in order to realise the guarantee proclaimed in the first part of the section (Currie and De Waal 2004). It is against the backdrop of this that the legislative arm of the government relying on section 24(b) continuously enact statutes which aim to protect environmental resources and regulate harmful impacts on the environment (NEMA, 1998).

It is worthy to mention that in terms of environmental management, the legislation make ample provisions for compliance and enforcement. The international environmental principles such as, the duty of care and the polluter pays are well entrenched in the legislation (ELI, 2007). In Section 2(4)(p) of NEMA, these principles help to create liability for environmental damage and provides for compliance with, and enforcement of environmental laws. When it comes to enforcement, section 31 of NEMA establishes an enforcement unit, the Environmental Management Inspectorate. Management, Inspectorate, monitoring are also established under NEMA in order to fulfil the environmental rights mandate as prescribed in the constitution.

The constitution stipulates that other measures should also be used to ensure realisation of environmental rights. Therefore, against this backdrop, environmental compliance and enforcement become necessary in order to ensure result (Boyle, 2006). In support of this constitutional imperative, the court, in the case of Khabisi NO and Another v Aquarella Investment 83 (Pty) Ltd and Others [2007] ZAGPHC 116 held that "the State and its organs, and their representatives, have an onerous constitutional mandate to promote conservation and protection of the environment." 
NEMA plays an important management role especially in Environmental Management Inspectors (EMIs), whose specific mandate it is to monitor and enforce compliance with South Africa's environmental regime, and to investigate potential offences and breaches of it (van Weele and Roods, 2011).

In discharging its international environmental obligation, South African is complying with its international compliance and enforcement obligations by putting in place strong institutions, and prescribing dedicated compliance and enforcement programmes in order for the country to achieving the goal of sustainable development (Weiss and Jacobson, 2000).

\section{Distortion in the Process of Food Production}

Distortion or interruption in the process of food that is from cultivation of the land up until planting will definitely lead to food unavailability and hunger will kick in (Adair, 2010). It is therefore important to curb any activity that will cause untold hardship to the people especially the poor. Fighting climate change causing in distortion in agricultural processes should be the responsibility of every body for the sake of food availability and prevention of food scarcity (Cribb, 2010).

Food is linked to human rights and sustainable development (Altieri, 2004). They are all interrelated and they are inseparable (Hussein, 2002). Availability of food promotes the right to sustainable food and development ( Vermeir and Verbeke, 2006). Hunger is anti-right to food and development (Guo, 2005). At all time, all should be done to ensure that climate change is tackled in order to assured human existence through food security (Beddington et al. 2012). Acute food shortage is a recipe for hunger and starvation which end result will be death (Oluseye, 2012).

\section{Demand and Supply of Food}

The impact of climate change is reducing the number of food output on a yearly basis (Parry et al. 2004). This is now having huge negative impact on supply of food for human consumption (Nellemann, 2009). Changes in local cropping patterns and farming practices are being distorted due mainly to the unpredictable nature of the weather events (Dahal, 2011). The concern is that, the impact of climate change on ecosystems and bio diversity is creating enormous scarcity of sea food which are mainly sources of protein (Garcia et al. 2010). In order to sustain this aspect of food production, there is need to ensure that regulations that are in place are strictly enforced (Henson and Caswell, 1999).

\section{Problem of Access to Food}

Majority of the poor in the rural areas rely mainly on agriculture as means of income to take care of their own socio economics needs including food (Banerjee and Duflo, 2007). Failure to produce enough to eat and sell will make access to adequate food difficult to the indigent poor because of the impact of climate change (Karmakar and Mukhopadhyay, 2014). Due to food scarcity, a family might reduce the daily amount of food consumed equally among all household members, or allocate food preferentially to certain members, often the able-bodied male adults, who are assumed to need it the most to stay fit and continue working to maintain the family (Edame et al. 2011). People might also not able to buy certain food as a result of climate impacts on income-earning opportunities because their incomes have been affected by the climate extremes which have invariably lead to unavoidable increase in their price (Satterthwaite et al. 2013). High prices may make certain foods unaffordable. This can have a negative impact on individuals' nutrition and health ( Dammann and Smith, 2009).

\section{Protecting Food Security by Bringing Down the Heat}

There is need to implement policies and enforce laws on mitigation strategies in order to avoiding future breakdowns in food and livelihood systems which will cause sharp increases in the number of food-insecure people worldwide and increase hunger and starvation (Pinstrup-Andersen and Pandya-Lorch, 1997).

All national and international initiatives on emissions reduction causing global climate change need to be adopted and implemented in the agriculture sector and by so doing, the benefits will be enormous because this will have multiple payoffs for food security and reduction in hunger and starvation (Hoffman, 2004). Considering that agricultural sector is one of the job creation avenues, the sector need to be protected from the impact of global climate change in order for it to continue to thrive and become more strengthened and sustainable (Verchot et al. 2007). In order to enhancing the sustainability of vulnerable livelihood systems, there is need to join hands together to reduce carbon emissions causing 
distortion and disruption to the agricultural sector (Paustian et al. 1997).

With regard to adapting to the impact of climate change and ensuring food security, hunger and starvation reduction and poverty alleviation, Ziervogel and Ericksen (2010) point out that "climate change poses considerable challenges to food security. Adapting food systems both to enhance food security for the poor and vulnerable and to prevent future negative impacts from climate change will require attention to more than just agricultural production...Food security can only be ensured and enhanced with a suite of interventions across activities, ranging from production to distribution and allocation... pulls together lessons from the literature on the type of institutional interventions that could be strengthened to enable adaptation in the food system to buffer against climate change at multiple levels, from the local to the global level" ( Ziervogel and Ericksen, 2010).

\section{Conclusion}

It has been demonstrated that for adequate food security, there is need to for regulatory interventions to curb the surge of climate change. These ample national and international instruments are powerful tools that will restore normalcy and secure food production and security. These can be achieved with the right political, administrative and enforcement wills.

\section{References}

Adair S 2010. Enterprise, relationship, and home: Voices of ecological farmers in a time of change. From http://gradworks.umi.com/34/29 /3429021.html. (Retrieved on 16 June, 2014).

Ahmed SA, Diffenbaugh NS 2009. Climate volatility deepens poverty vulnerability in developing countries. From http://iopscience.iop.org/1748-9326/4/3/034004. (Retrieved on 4 April, 2014).

Altieri MA 2004. Linking ecologists and traditional farmers in the search for sustainable agriculture. Frontiers in Ecology and the Environment, 2: 35-42.

Banerjee AV, Duflo E 2007. The economic lives of the poor. From http://www.ncbi.nlm.nih.gov/pmc/articles/PMC2638067/. (Retrieved on 14 March, 2014).

Barnett HJ, Morse C 2013. Scarcity and growth: The economics of natural resource availability. RFF Press, New York, USA.

Beddington J, Asaduzzaman M, Fernandez A, Clark M 2012. Achieving food security in the face of climate change: Final report from the Commission on Sustainable Agriculture and Climate Change. From http://scholar.google.co.za/scholar?hl=en\&q= security\&btnG=\&as_sdt=1\%2C5\&as_sdtp=. (Retrieved on 16 July, 2014).

Beder S 1996. The Nature of Sustainable Development, 2nd edition, Scribe, Newham.

Bodansky D 2001. The history of the global climate change regime. From http://books.google.co.za/books?hl=en\&lr= \&id=bksixrsynqoc \&oi=fnd\&pg=pa23\&dq=it+is+a+ =ewod_gody2\&sig=luvwdpu05xbcxawwuxca9u0b4uc\#v=onepage\&q\&f=false. (retrieved on 29 march, 2014).

Boyle A 2006. Human Rights or Environmental Rights - A Reassessment. Fordham Environmental Law Review, 18:471-482.

Cameron J, Abouchar J 1991. The Precautionary Principle: A Fundamental Principle of Law and Policy for the Protection of the Global Environment, 14 B.C. Int'l \& Comp. L. Rev. 1 (1991).

Cribb J 2010. The coming famine: the global food crisis and what we can do to avoid it. University of California Press, Los Angeles, USA.

Dahal DS 2011. Impact of Climate Change on Livelihood and Biodiversity in Rural Communities (A Case Study of SiddhiGanesh and Nepane Community Forestry User Groups. From http://www.forestrynepal.org/images/thesis/MA_DSDahal.pdf. (Retrieved on 4 August, 2014).

Dammann KW, Smith C 2009.Factors Affecting Low-income Women's Food Choices and the Perceived Impact of Dietary Intake and Socioeconomic Status on Their Health and Weight . Journal of Nutrition Education and Behavior. 41(4): 242-253.

Denton F J, Thomas P, Sokona Y 2002. Climate Change and Sustainable Development Strategies: An Agenda for Long Term Action, OECD Environment and Development Co-operation, Paris: OECD.

der Linde V 2002. African Responses to Environmental Protection' (2002) 35 Comparative International Law Journal of Southern Africa 99.

Dietz T, Rosa EA, York R 2009. Environmentally efficient well-being: Rethinking sustainability as the relationship between human wellbeing and environmental impacts. From http://ajph.humanecologyreview.org/pastissues/her161/dietzetal.pdf. (Retrieved on 16 April, 2014).

Du Toit A, Ziervogel G 2004. Vulnerability and food insecurity: Background concepts for informing the development of a national FIVIMS for South Africa. From www.agis.agric.za/agisweb/FIVIMS_ZA. (Retrieved on 11 June, 2014).

Easterling W E, Aggarwal PK, Batima P, Brander KM, Erda L, Howden SM, Kirilenko A, Morton J, Soussana JF, Schmidhuber J, Tubiello DFN 2007. Food, fibre and forest products," in Climate Change 2007: Impacts, Adaptation and Vulnerability. Contribution of Working Group II to the Fourth Assessment Report of the Intergovernmental Panel on Climate Change, ed. M. L. Parry, O. F. Canziani, J. P. Palutikof, P. J. van der Linden and C. E. Hanson (Cambridge, United Kingdom: Cambridge University Press.

Edame GE, Anam BE, Fonta WM, Duru EJC 2011. Climate change, food security and agricultural productivity in Africa: issues and policy directions. International Journal of Humanities and Social Science, 1(21): 205-223. 
Ekins P 2002. Economic growth and environmental sustainability: the prospects for green growth. Routledge, New York, USA.

ELI 2007. Environmental Law Institute. Constitutional environmental law: Giving force to fundamental principles in Africa. United Nations Environmental Programme, Washington, USA.

Ferreira GM 1999. Volhoubare Ontwikkeling, Regverdige Ontwikkeling en die Fundamentele Reg op 'n Skoon en Gesonde Omgewing (1999) 3 SALJ 436-437.

Fuggle RF, Rabie MA, Strydom HA, King ND 2009. Environmental Management in South Africa. Juta \&Co, Cape Town, South Africa.

Garcia SM, Rosenberg AA 2010. Food security and marine capture fisheries: characteristics, trends, drivers and future perspectives. Philosophical Transnational Research Sociology. 365( 1554): 2869-2880.

Giorgetta S 2004. The right to a healthy environment, in NicoSchrijver and Friedl Weiss (eds.) International law and sustainable development: Principles and practice. MartinusNijhoff Publishers, Leiden, Boston, USA.

Gregory PJ, Ingram JSI 2005. Climate change and food security. Philosophical Transnational Research Social, 360(1463): $2139-2148$.

Guo D 2005. Nature of Human Rights and Analysis of Its Value Status. US-China Law Review, 2:7-16.

Henson S, Caswell J 1999.Food safety regulation: an overview of contemporary issues. Food Policy, 24(6): 589-603.

Hoffman AJ 2004. Climate change strategy: The business logic behind voluntary greenhouse gas reductions. From http://deepblue.lib.umich.edu/handle/2027.42/39160. (Retrieved on 27 March, 2014).

HST 2007. The South African Health Review (1995-2007), published by the Health Systems Trust, has detailed this discrepancy very eloquently over the last 12 years. From <http://www.hst.org.za/generic/29>. (Retrieved 23 July, 2014).

Hussein K 2002. Food Security: Rights, Livelihoods and the world food summit-five years later. From http://onlinelibrary.wiley. com/doi/10.1111/1467-9515.00308/full. (Retrieved on 16 June, 2014).

JPI 2002. Johannesburg Plan of Implementation, Report of the World Summit on Sustainable Development, Johannesburg, South Africa, UN Document A/CONF.199/20. From http://www.un.org/esa/sustdev/documents/WSSD_POI_PD/English/POIToc.htm. (Retrieved on 29 December 2013).

Karmakar A K, Mukhopadhyay D 2014. Towards a Prudent Policy for Food Security in India. US-China Law review, 11: $221-232$.

Labuschagne C, Brent Ac, van Erck RPG 2005. Assessing the sustainability performances of industries. Journal of Cleaner Production. Volume 13, Issue 4, March 2005, Pages 373-385.

Lafferty WM 1996. The politics of sustainable development: Global norms for national implementation. Environmental Politics. 5(2): 185208.

Lutter R 2000. Developing Countries' Greenhouse Emissions: Uncertainty and Implications

Mainka S, McNeely J, McNeely JA, Jackson B 2005. Depend on nature: ecosystem services supporting human livelihoods. From http://books.google.co.za/books?hl=en\&lr=\&id=t5d0uozqboec\&oi=fnd\&pg=pa2\&dq=majority+of+ 1nmbbwvvj5\&sig=vdlmhggjkqqk7-5x1idmbvfdbu4\#v=onepage\&q\&f=false. (Retrieved on 24 July, 2014).

Marcuse P 1998. Sustainability is not enough. Environment and Urbanization, 10(2): 103-112.

Martínez-Alier J 1993. Distributional obstacles to international environmental policy: the failures at Rio and prospects after Rio. Environmental Values, 2(2): 97-124.

Nellemann C 2009. The Environmental Food Crisis: The Environment's Role in Averting Future Food Crises: a UNEP Rapid Response Assessment.

Fromhttp://books.google.co.za/books?hl=en\&lr=\&id=bo6d5mbc42cc\&oi=fnd\&pg=pa9\&dq=ai76v9vmy\&sig=q9ylzb3hf4no8etgwie7 crkesiu\#v=onepage\&q\&f=false. (Retrieved on 14 August, 2014).

NEMA 1998. The National Environmental Management Act 107 of 1998.

NFSD 2008. A National Framework for Sustainable Development in South Africa JULY 2008.

Oluseye MO 2012. Subsistence Farming: Antidote to Famine and Food Insecurity. From http://scholar.google.co.za/scholar?hl=en\&q= btnG=\&as_sdt=1\%2C5\&as_sdtp=. (Retrieved on 1 August, 2014).

Parry ML, Rosenzweig C, Iglesias A, Livermore M, Fischer G 2004. Effects of climate change on global food production under SRES emissions and socio-economic scenarios. Global Environmental Change, 14(1): 53-67.

Paustian K, Andren O, Janzen HH, Lal R, Smith P, Tian G, Tiessen H, Van Noordwijk M, Woomer PL 1997. Agricultural soils as a sink to mitigate carbon dioxide emissions. Soil use and management, 13(4): 230244.

Peart P, Wilson J 1998. Environmental policy-making in the new South Africa, South African Journal of Environemntal Law and Policy, 5: 240-252.

Pinstrup-Andersen P, Pandya-Lorch R 1997. A 2020 vision for food, agriculture, and the environment in Southern Africa. International Food Research Policy Institute, Washington, USA.

Policy for the Protection of the Global Environment, 14 B.C. Int'I \& Comp. L. Rev. 1 (1991).

Rajamani L 2000. The Principle of Common but Differentiated Responsibility and the Balance of Commitments under the Climate Regime", RECIEL. 9(2), pp: 120-131.

Redclift M 1993. Sustainable development: needs, values, rights. Environmental Values, 2(1): 3-20.

Rigg J 2006. Land, farming, livelihoods, and poverty: Rethinking the links in the Rural South. World Development, 34(1): 180-202.

Ruel, MT, Garrett J, Morris S, Maxwell D, Oshaug A, Engele P, Menon P, Slack A, Haddad Ruel MT, Garrett JL, Morris SS, Maxwell D, Oshaug A 1998. Urban challenges to food and nutrition security: a review of food security, health and caregiving in the cities. IFPRI FCND Discussion Papers No. 51. Washington, DC, IFPRI. From http://scholar.google.co.za/scholar?q= btnG=\&hl=en\&as_sdt=0\%2C5. (Retrieved on 16 April, 2014).

Satterthwaite D, Reid H, Bass S 2013. Reducing Poverty and Sustaining the Environment: The politics of local engagement. Earthscan, 
London, UK.

Smith P, Martino D, Cai Z, Gwary D, Janzen H, Kumar P, McCarl B, Ogle S, O'Mara F, Rice C, Scholes B, Sirotenko O, Howden M, McAllister T, Pan G, Romanenkov V, Schneider U, Towprayoon S 2007. Policy and technological constraints to implementation of greenhouse gas mitigation options in agriculture. Agriculture, Ecosystems \& Environment, 118(1-4): 6-28.

Sneddon C, Howarth RB, Norgaard RB 2006. Sustainable development in a post-Brundtland world. Ecological Economics, 57(2): 253268.

Stewart and Horsten D 2009. The role of sustainability in the adjudication of the right to access adequate. From http://reference.sabinet.co.za/sa_epublication_article/sapr_v24_n2_a12. (Retrieved on 29 May, 2014).

Tubiello FN, Amthor JA, Boote K, Donatelli M, Easterling WE, Fisher G, Gifford R, Howden M, Reilly J, Rosenzweig C 2007. Crop response to elevated CO2 and world food supply. European Journal of Agronomy, 26: 215_228.

UNFCCC. 2007, Climate Change Impacts, Vulnerabilities and Adaptation in the Developing Countries From http://unfccc.int/resource/docs/publications/impacts.pdf. (Retrieved on 21 March, 2014).

Van der Linde M, Basson E 2005. Environment' in Woolman et al (eds) Constitutional Law of South Africa 2 ed (2005.)

Van Reenen T 1997. 'Constitutional Protection of the Environment: Fundamental (Human) Right or Principle of State Policy?' (1997) 4 South African Journal of Environmental Law and Policy.

Van Weele G, Roods M 2011. Department of Environmental Affairs. From https://www.environment.gov.za/sites/default /files/docs/eiams_subtheme8.pdf. (Retrieved on 12 June, 2014).

Verchot LV, Van Noordwijk M, Kandji S, Tomich T, Ong C, Albrecht A, Mackensen J, Bantilan C, Anupama KV, Palm C , 2007. Climate change: linking adaptation and mitigation through agroforestry, Mitigation and Adaptation Strategies for Global Change, 12(5): 901-918.

Vermeir I, Verbeke W 2006. Sustainable Food Consumption: Exploring the Consumer "Attitude - Behavioral Intention" Gap. Journal of Agricultural and Environmental Ethics, 19(2):169-194.

Wackernagel M, Rees W 1998. Our ecological footprint: reducing human impact on the earth. From http://books.google.co. za/books?hl=en\&lr=\&id=wvneaqaaqbaj\&oi=fnd\&pg=pr9\&dq=if+this+ vksk3kukpu\&sig=4sotiua_ys2smn6viamdqs657sk\#v=onepage\&q\&f=false. (Retrieved on 14 February, 2014).

Weiss EB, Jacobson HK 2000. Engaging countries: strengthening compliance with international environmental accords. MIT Press, Massachusetts, USA. (Retrieved on 11 January, 2014).

Yamin F, Depledge J 2004. The international climate change regime: a guide to rules, institutions and procedures. Cambridge University Press, Cambridge, UK.

Zehetner GS 2013. Environmentally induced migration and the concepts vulnerability, resilience and adaptation to climate change. From http://othes.univie.ac.at/28676/. (Retrieved on 24 July, 2014).

Ziervogel G, Ericksen P 2010 Adapting to climate change to sustain food security. Climate Change, 1(4): 525-540. 